The BDJ News section accepts items that include general news, latest research and diary events that interest our readers. Press releases or articles may be edited, and should include a colour photograph if possible. Please direct your correspondence to the News Editor, Arveen Bajaj at the BDJ, 64 Wimpole Street WIG 8YS or by email to bdj@bda.org

\section{Chair appointed}

Val Clerehugh was recently awarded a Personal Chair in Periodontology at Leeds Dental Institute, where she is also Director of Postgraduate Research Studies.

Her research interests include periodontal epidemiology and microbiology in adolescents and young Type 1 diabetes patients.

After graduation from Manchester, Dr Clerehugh worked in the Community Dental Service in Barnsley and subsequently gained her $\mathrm{PhD}$ at the University of Manchester Dental Health Unit. Following lecturer posts, she moved across the Pennines to Leeds in 1994 as Senior Lecturer in Restorative Dentistry.

She has been Member of Council and Honorary Editor of the British Society of Periodontology since 1999, and will be President-elect in 2006.

She is also a clinical editor of the British Dental Journal and after a 10-year stint as associate editor, is on the editorial board of Journal of Dentistry. Terms of office completed include Chair and Secretary of the Periodontal Research Group of the British Society of Dental Research.

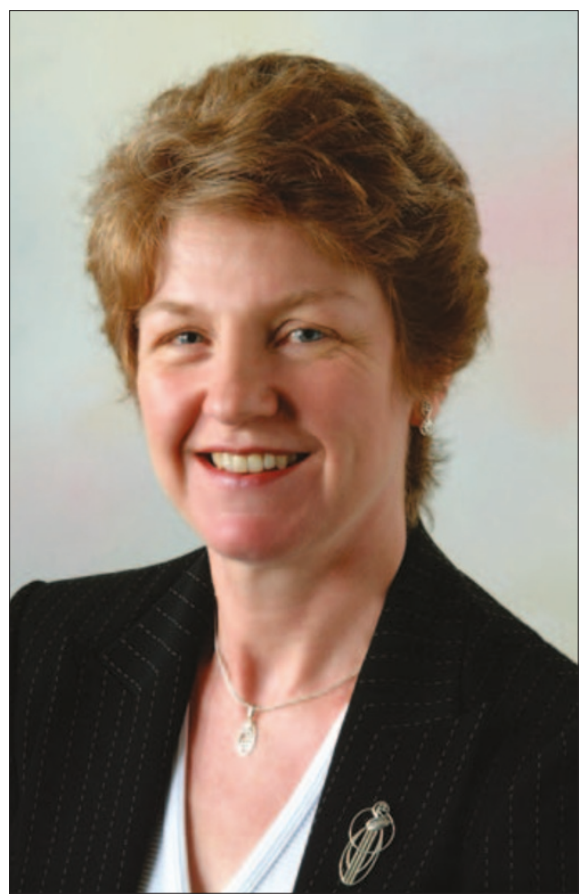

\title{
On your marks
}

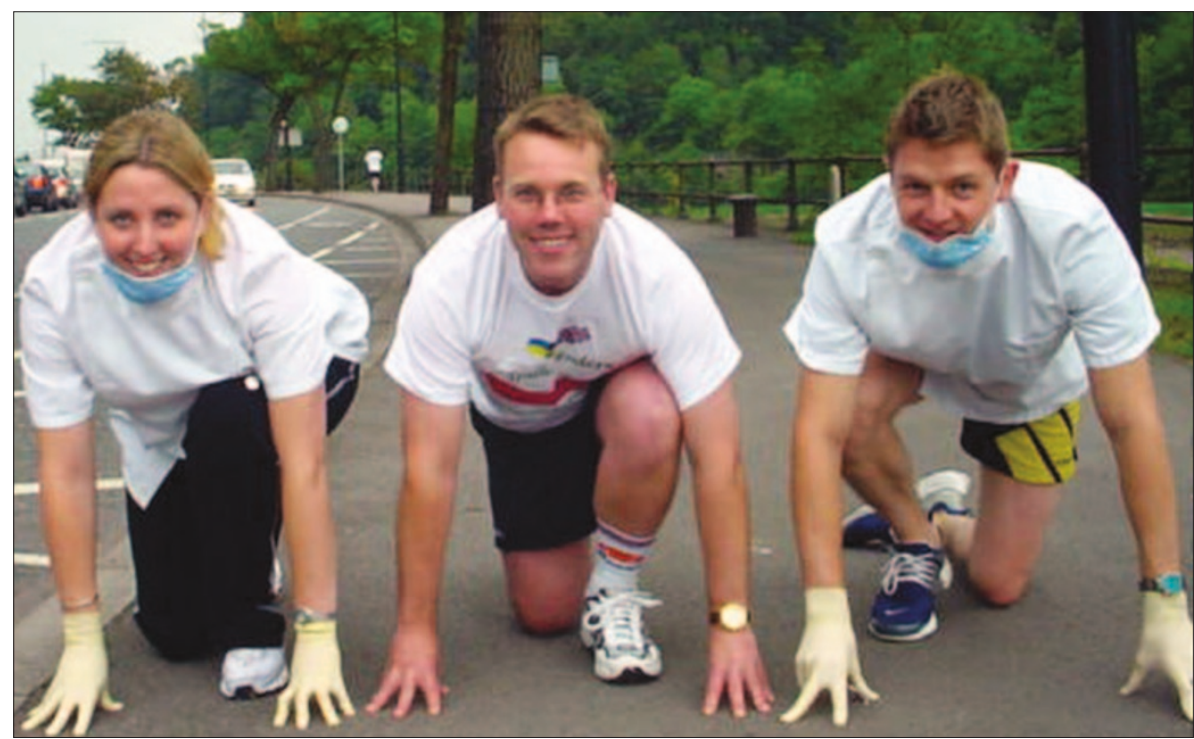

Three entrants in the Bristol Half Marathon get set to raise money for the dental aid charity Smilemenders with a view to sponsoring the training of a Ukrainian, Valery Perikopskiy, in dental engineering. The two aerospace engineers, John Warbutton and Phil Curnock, and sales training consultant and Smilemenders volunteer Laura Sargent, raised the cash so that Valery Perikopskiy could receive training in the UK for up to four months and be equipped to service surgeries donated by Smilemenders and possibly those provided by other charities, on his return home. Pictured from left to right, Laura Sargent, John Warbutton and Phil Curnock.

\section{PCD registration developments}

The GDC has approved, in principle, the development of an additional route for dental nurses to gain statutory registration during the transitional period.

This is based on a minimum of two years' experience plus satisfactory proof of competence in the areas covered by the proposed new top-up training programme, or satisfactory completion of the proposed training.

It asked the Registration Committee to develop proposals for establishing that competence, for approval by Council.

It has also approved a revised Council policy on dental technician registration. During the two-year transitional period, dental technician registration should be open to dental technicians with an approved qualification, and dental technicians on the voluntary register held by the Dental Technicians Association. In addition it should also be open to unqualified applicants who have verifiable evidence that they have been satisfactorily employed as a dental technician for seven years in the last ten (or the part-time equivalent) and to those who have the ability to manage the manufacture of a range of custom-made dental devices within fixed or removable prosthodontics or orthodontics.

After the end of transition, only qualified dental technicians should be allowed to register.

Finally, only registered dental technicians, or those under supervision and enrolled on a course leading to registration as a registered dental technician with the GDC, should be directly involved in the manufacture of dental appliances. 


\section{DIARY}

October 2004

Leeds Dental School Centenary

Date: 16.10.04

Venue: Leeds

Contact: Gayle Williams

Tel: +44 (0) 1133436138

Email: g.williams@leeds.ac.uk

\section{January 2005}

International Dental Foundation 54th International Alpine Dental Conference

Date: 29.01.05-05.02.05

Venue: Hotel Annapurna, Courcheval 1850, France

Contact: Robert Wallace

Tel: +44 (0) 2072350788

Fax: +44 (0) 2072350767

Email: idf@idfdentalconference.com www.idfdentalconference.com

\section{March 2005}

83rd General Session \& Exhibition of the IADR, 34th Annual Meeting of the AADR, 29th Annual Meeting of the CADR

Date: 9-12.03.05

Venue: Baltimore Convention Centre, Maryland

www.dentalresearch.org

\section{April 2005}

Academy of Laser Dentistry 12th Annual Conference \&t Exhibition

Date: 6-9.04.05

Venue: Marriott New Orleans, Louisiana Tel: 18775273776

Email:

memberservices@laserdentistry.org www.source2005.org

\section{Child-friendly initiative}

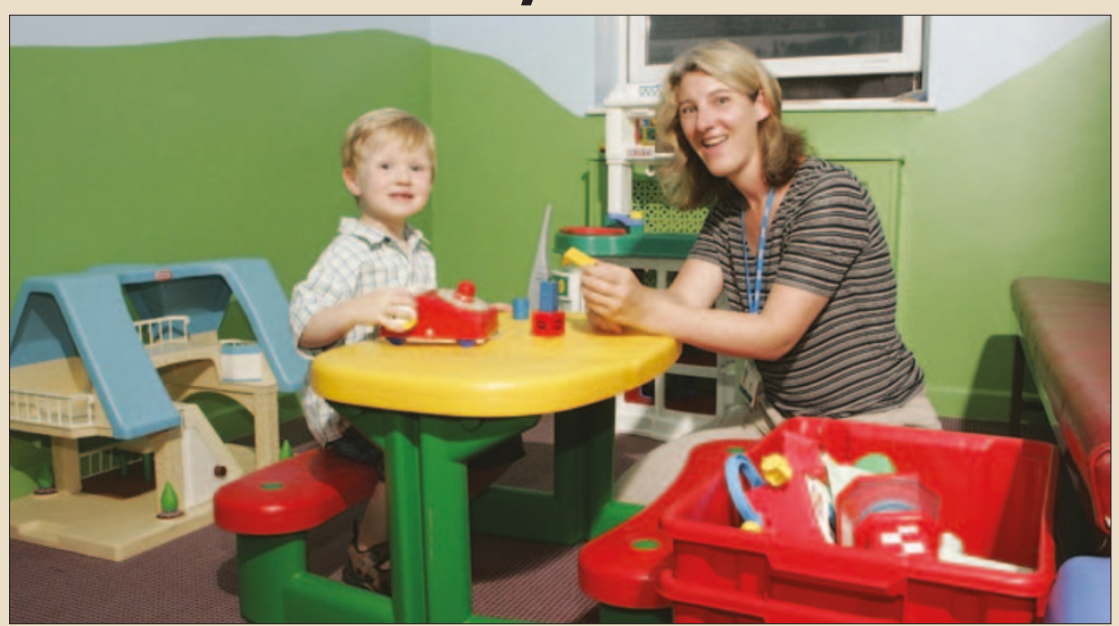

Caroline Fawcett is the UK's first hospital play specialist to be employed by the Eastman Dental Hospital and Institute. The post was created following recommendations by the Kennedy Action Group and is funded as part of a research post.

Caroline will be developing a childfriendly and welcoming environment for children and teenagers visiting the $\mathrm{EDH}$ for treatment. Her role involves planning and supervising activities for children while they are at the EDH and using therapeutic play and preparation to help them overcome anxieties they may have with regard to their dental visits.

According to Caroline Fawcett, a dental hospital, by its nature, is very clinical and can be daunting for children. Her job is to provide support and therapeutic play that can help children and teenagers undergo dental treatment and procedures, with the minimum of anxiety. Play specialists have been working in hospital settings for some time, but until now, have not been present in dental settings.

The hospital hopes that the new appointment will be an opportunity to introduce and develop child focussed play provision at the EDH and to make a positive difference to a child or young person's experience of a dental hospital.

As a qualified Hospital Play Specialist, Caroline has moved from the Newcastle upon Tyne Hospitals NHS Trust where she has nine years experience of working in acute paediatric services and has implemented a variety of innovative approaches to help children cope well in the healthcare setting.

Over a two year period her impact at EDH will be audited as part of the remit of this appointment. 


\section{Wild wild West comes to UK}

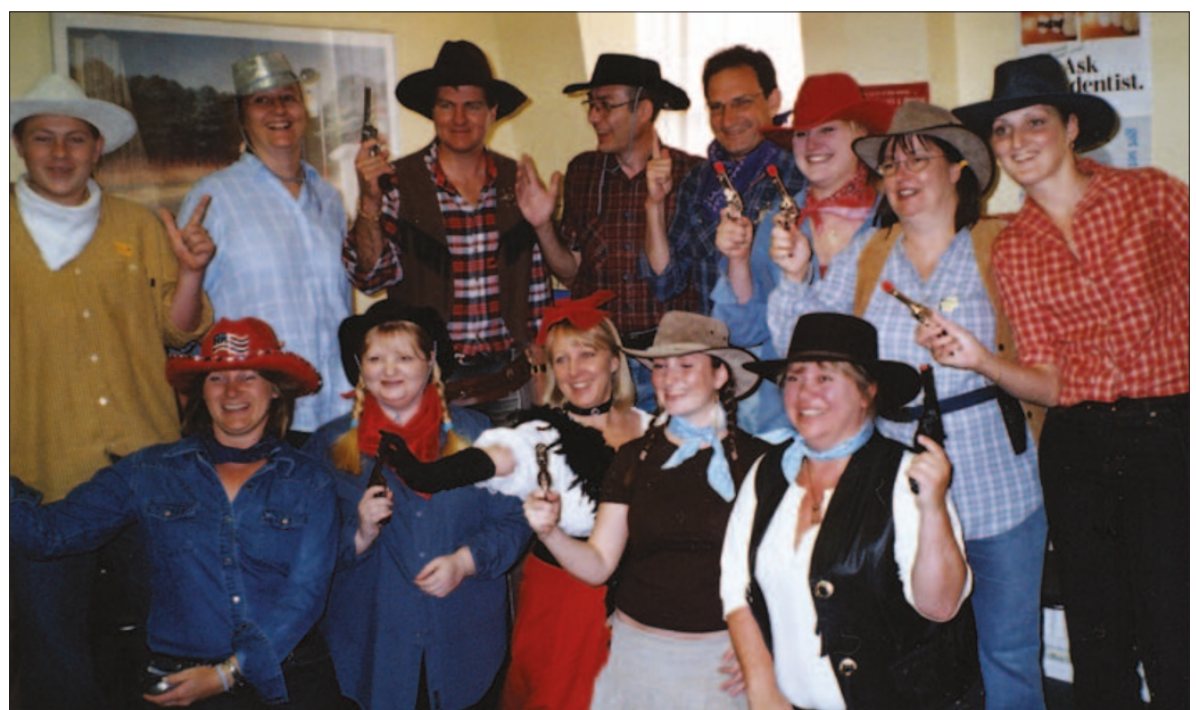

Staff at the Integrated Dental Holdings practice in Dolphin Square took part in the national 'Dress Up for Dentaid Day' to raise money for the dental charity, which is dedicated to helping the developing world improve oral healthcare. All the dental staff abandoned their uniforms for the day in favour of a Western look, and the surgery was populated by cowboys and showgirls. Whilst going about normal surgery life, staff managed to raise around $€ 80$ in donations from both staff and patients.

\section{Helping the homeless this Christmas}

As Christmas fast approaches, many of the UK's charity organisations look to the professional community to lend their support by volunteering to help in a practical way.

One such charity is Crisis, the national homelessness charity, who is appealing for dentists, dental nurses and hygienists to volunteer their skills to help homeless people this Christmas.

Last year, over 1,200 homeless and vulnerable people visited the Crisis Open Christmas shelters based in London. The shelters offer warmth, food, companionship and access to services during the festive season. The dentists, dental nurses and hygienists are a key part of the 500 professional medics who are needed to volunteer for a range of shifts and hours between 23 and 30 December.

Dental Service Organiser, Liz Deuchars, says that the medical centre was visited by three quarters of guests last year. She adds that as many homeless people have little or no access to health services, the medical centre provides a vital lifeline.

The dentists, dental nurses and hygienists are key in treating guests who may not have visited a dentist for some time, and so the charity needs as much help as possible and urges people to get involved in order to make a difference to homeless people this Christmas.

The dental team is part of the 3,000 strong team of volunteers who give up their time over Christmas to run the shel- ters. The time given by all the volunteers is estimated to be worth over $£ 600,000$ but according to Crisis, more important is the warmth and understanding that guests receive from the volunteers.

One third of guests sleep rough with the rest part of the hidden homeless population, who are trapped in hostels, B\&Bs or other temporary accommodation.

The volunteer hotline is 0207426 3872, email coc@crisis.org.uk or apply online at www.crisis.org.uk.

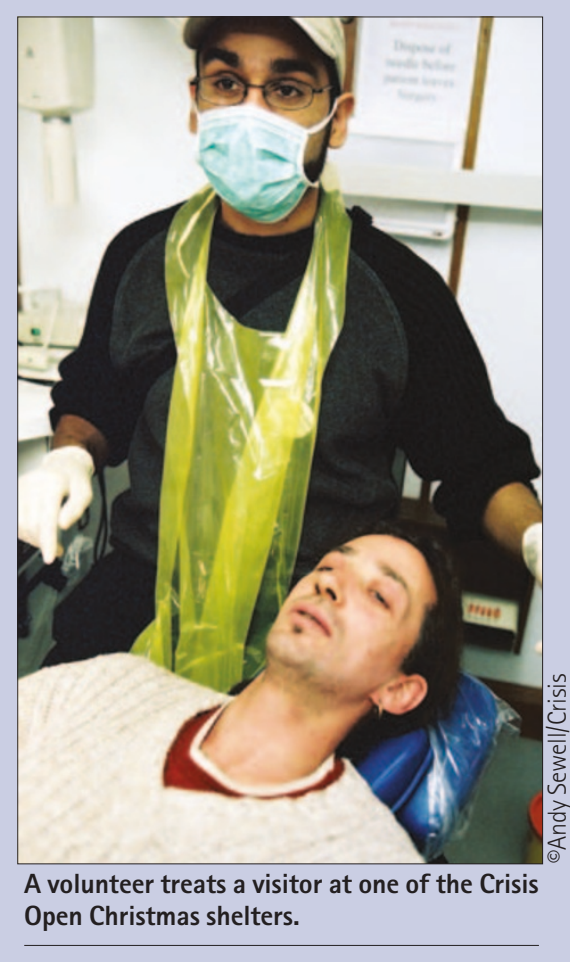

